\title{
Tracking nutrient and productivity variations over the last deglaciation in the Arctic Ocean
}

\author{
Carsten J. Schubert \\ Max Planck Institute for Marıne Microbiology, Bremen, Germany \\ Ruediger Stein \\ Alfred Wegener Institute for Polar and Marine Research, Bremerhaven, Germany \\ Stephen E. Calvert \\ Earth and Ocean Sciences, Unıversity of Bntısh Columbia, Vancouver, Britısh Columbia, Canada
}

\begin{abstract}
We have reconstructed the surface water environment of the Arctic Ocean over the last $\sim 50,000$ years using measurements of the organic nitrogen and carbon isotope ratios, carbonate and total organic carbon concentrations (TOC), and terrestrial biomarkers (lignin and long-chain $n$-alkanes) in four multicores. Variations in nitrogen isotope ratios that are concordant with TOC and carbonate concentrations (representing foraminifera and excluding ice-rafted-debris) reflect differences in relative nutrient utilization of phytoplankton in the surface waters. However, $\delta^{15} \mathrm{~N}$ variations also appear to be dependent on the stratification of the water column and therefore potentially track the exchange of nutrients between deep and surface waters. Low Last Glacial Maximum (LGM) $\delta^{15} \mathrm{~N}$ values and higher Holocene values are opposite to those recorded in the Southern Ocean. The Arctic Ocean with higher nutrient utilization today compared to the LGM therefore acts as a counterpart to the Southern Ocean, although the global impact on carbon dioxide variations compared to the Southern Ocean is probably low.
\end{abstract}

\section{Introduction}

The Arctic Ocean is unique compared to other oceans in being an enclosed sea and in having a more or less year round sea -ice cover. Since the Arctic Ocean is surrounded by large shelf areas, a close interaction between land and ocean takes place. Today, for example, $10 \%$ of the global river runoff, namely, $3300 \mathrm{~km}^{3} \mathrm{yr}^{-1}$ freshwater, is introduced into the Arctic Ocean by major rivers, ensuring the maintenance of an $\sim 200 \mathrm{~m}$ thick low-salinity layer [Stein, 2000]. This surface water body is especially important since its low salinity facilitates sea ice formation.

The permanent sea ice cover strongly influences Earth's albedo, the marine ecosystem, and sedimentation. Whereas in other oceans nutrient availability in surface water acts as a major control on productivity, here variations in sea ice cover and therefore light conditions may be even more important. The waxing and waning of the sea ice cover as a result of changing river inflow has a large impact on the energy budget and albedo as well as the temperature and salinity structure of the upper water masses [Driscoll and Haug, 1998]. Additionally, sea ice works as a transport system for sediments that are entrained on the shelves and released over the ocean [Wollenburg, 1993; Nürnberg et al., 1994].

Although the use of icebreaking research vessels has made it possible during the last decade to perform research in the permanently ice-covered Arctic Ocean, it still represents a region where our knowledge is very scanty. It is important to understand the Arctic Ocean system in order to understand its

Copyright 2001 by the American Geophysical Union

Paper number 2000PA000503

0883-8305/01/2000PA000503\$12 00 role in the global carbon cycle and its influence on global climate. In particular, estimates of the organic carbon flux with respect to the restriction of "high" productivity by the sea ice cover are necessary.

The nitrogen isotopic composition of sedimentary organic matter can be used to track nutrient $\left(\mathrm{NO}_{3}{ }^{-}\right)$utilization in the overlying surface waters [Altabet and Francois, 1994a; Francois et al., 1992; Farrell et al., 1995]. The isotope proxy is based on the observation that particulate organic matter (POM) $\delta^{15} \mathrm{~N}$ depends on (1) the isotopic composition of the nitrogenous substrate, which has a $\delta^{15} \mathrm{~N}$ of 4-6\% [Voss et al., 1996; Wu et al., 1997; Sigman et al., 1997, 2000] and (2) isotope fractionation that occurs during nitrogen uptake by phytoplankton [Wada and Hattori, 1991]. In the photic zone, there is preferential uptake of ${ }^{14} \mathrm{NO}_{3}{ }^{-}$by phytoplankton, giving rise to photosynthate enriched in the light isotope and to a residual dissolved $\mathrm{NO}_{3}{ }^{-}$pool that is correspondingly and progressively enriched in ${ }^{15} \mathrm{~N}$. The nitrogen isotopic composition of settling organic detritus will vary depending on the extent of nutrient ut1lization (biological uptake relative to physical supply), lighter values indicatıng low relative utilization and heavy values indicating a high utilization of the nutrient pool. This effect is clearly seen in the equatorial Pacific, where the lower latitude surface sediments have low $\delta^{15} \mathrm{~N}$ of $4-6 \%$, whereas the sediments to the north and south of the equator have progressively higher $\delta^{15} \mathrm{~N}$ because the available nutrient pool is isotopically enriched by the progressive drawdown of nitrate [Altabet and Francois, 1994a; Farrell et al., 1995]. This interpretation is complicated in regions of significant subsurface water column denitrification, which results in the production of isotopically heavy nitrate [Liu and Kaplan, 1989], which if it is mixed into the photic zone, can produce isotopically heavy particulate 


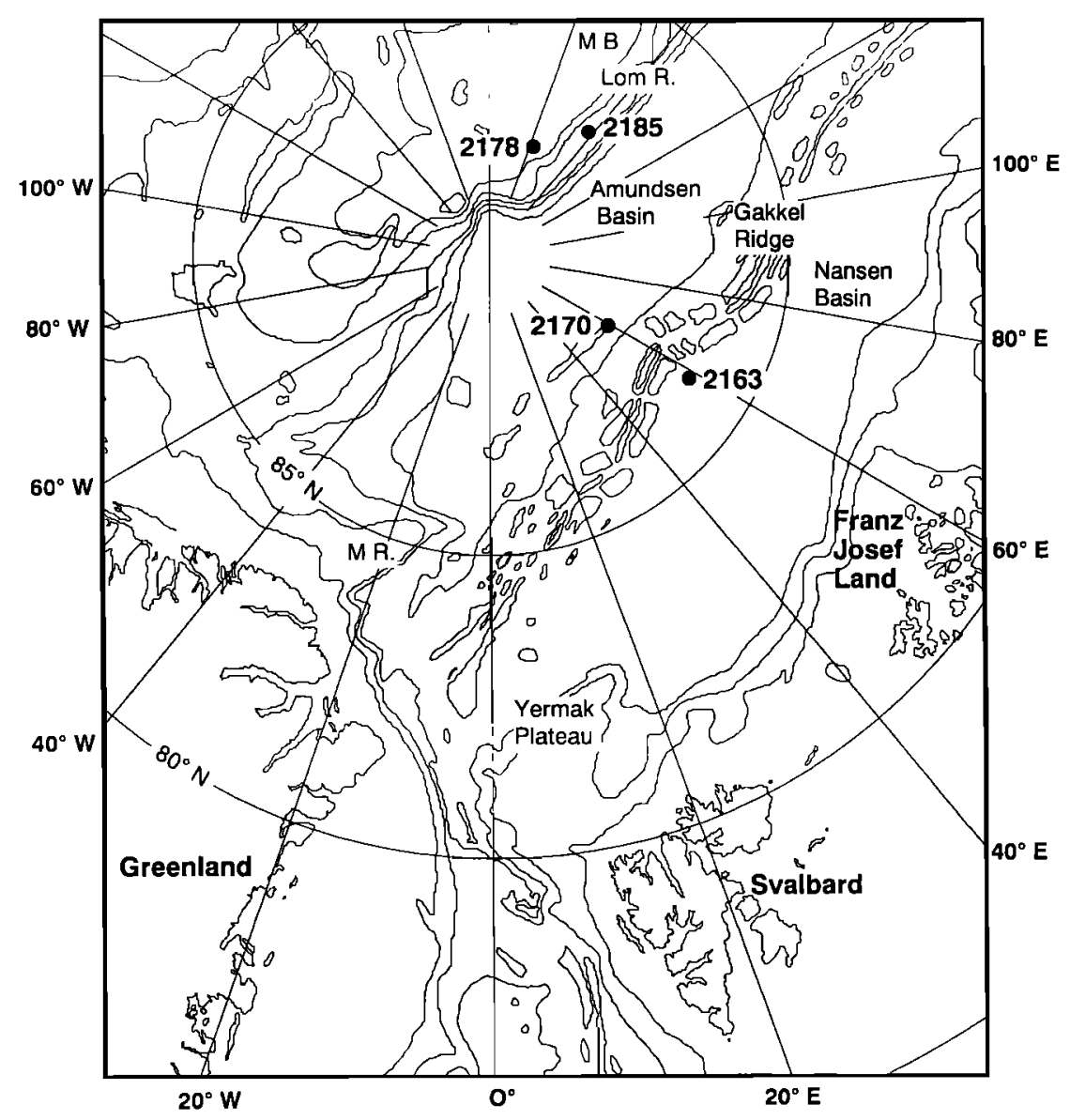

Figure 1. Core locations of the four multicorer cores used in this study (Lom.R. , Lomonossov Ridge; M.B., Makarov Basin; M.R., Morris Yesup Rise).

organic matter even in areas of high production and low relative nutrient utilization [Pride et al., 1999]. With suitable precautions therefore it is possible to interpret variations of the sedimentary nitrogen isotope signal with respect to changes in either the source of nutrients or relative nutrient utilization that occur in connection with surface water productivity. Both processes in the Arctic Ocean over the last 50,000 years are examined in this paper, with respect to other proxies of productivity, namely, the total organic carbon (TOC) content and accumulation rate, the carbonate (foraminiferal content), and the carbon isotopic composition of the sedimentary organic matter.

\section{Material and Methods}

Four multicorers (PS2163-1, Gakkel Ridge; PS2170-4, Amundsen Basin; PS2178-4, Makarov Basin; and PS2185-4,
Lomonosov Ridge) recovered durıng RV Polarstern cruise ARCTIC '91 Expedition [Fütterer, 1992] were selected for this study (Figure 1 and Table 1). The cores were cut on board into $1 \mathrm{~cm}$ slices and either immediately frozen at $-30^{\circ} \mathrm{C}$ or stored at $4^{\circ} \mathrm{C}$. The lithology of Arctic Ocean sediments is dominated by brown to gray to olive silty clays to clayey silts; sand is a minor component [Fütterer, 1992; Stein et al., 1994b].

Total carbon (TC) and total nitrogen were determined on ground bulk samples using a Heraeus $\mathrm{CHN}$ analyzer. Total organic carbon (TOC) was determined on carbonate-free subsamples using the same technique. The carbonate content was calculated as $\mathrm{CaCO}_{3}=(\mathrm{TC}-\mathrm{TOC}) \times$ 8.33. Precision was better than $\pm 1.2 \%$.

Nitrogen and carbon isotope ratios were determined on the bulk and decarbonated samples, respectively. Sediments were combusted in an on-line Fisons NA 1500 element analyzer

Table 1. Core Locations, Water Depths, TOC Accumulation Rates and $\delta^{15} \mathrm{~N}$ Values for Modern and LG for the Four Cores

\begin{tabular}{|c|c|c|c|c|c|c|c|}
\hline Station & $\begin{array}{c}\text { Latitude, } \\
{ }^{\circ} \mathrm{N}\end{array}$ & $\begin{array}{c}\text { Longitude, } \\
{ }^{\circ} \mathrm{E}\end{array}$ & $\begin{array}{c}\text { WD, } \\
\text { m }\end{array}$ & $\begin{array}{l}\text { AR TOC Mod., } \\
\mathrm{mg} \mathrm{cm}^{-2} \mathrm{kyr}^{-1}\end{array}$ & $\begin{array}{l}\text { AR TOC LG, } \\
\mathrm{mg} \mathrm{cm}^{-2} \mathrm{kyr}^{-1}\end{array}$ & $\begin{array}{c}\delta^{13} \text { N Mod., } \\
\%\end{array}$ & $\begin{array}{c}\delta^{\text {IS N LG, }} \\
\%\end{array}$ \\
\hline PS2163-1 & $86^{\circ} 14.5^{\prime}$ & $59^{\circ} 129^{\prime}$ & 3040 & 2.9 & $<1.5$ & 5.5 & 3.6 \\
\hline PS2163-1 & $87^{\circ} 35.8^{\prime}$ & $60^{\circ} 53.7^{\prime}$ & 4083 & 4.5 & 1.5 & 6.2 & 4.6 \\
\hline PS2178.4 & $88^{\circ} 01.3^{\prime}$ & $159^{\circ} 35.1^{\prime}$ & 4008 & 1.6 & 0.6 & 6.0 & 4.4 \\
\hline PS2185-4 & $87^{\circ} 30.0^{\prime}$ & $144^{\circ} 28.9^{\prime}$ & 1051 & 2.7 & 0.6 & 6.6 & 4.0 \\
\hline
\end{tabular}

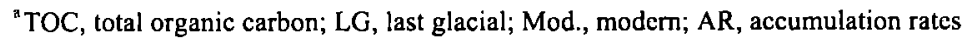


and the evolved $\mathrm{N}_{2}$ or $\mathrm{CO}_{2}$ was passed to a VG PRISM isotope-ratio mass spectrometer in a continuous flow of $\mathrm{He}$. Results are reported in the $\delta$ notation, $\delta^{15} \mathrm{~N}=\left\{\left({ }^{15} \mathrm{~N} /{ }^{14} \mathrm{~N}\right)_{\text {sample }} /\left({ }^{15} \mathrm{~N} /{ }^{14} \mathrm{~N}\right)_{\text {standard }}-1\right\}$ per mil, relative to atmospheric $\mathrm{N}_{2}$ and $\delta{ }^{13} \mathrm{C}=\left\{\left({ }^{13} \mathrm{C} /{ }^{12} \mathrm{C}\right)_{\text {sample }}\right.$ $\left.\left({ }^{13} \mathrm{C} /{ }^{12} \mathrm{C}\right)_{\text {standard }}-1\right\}$ per mil, relatıve to pee dee belemnite (PDB). Measurement precision was better than $0.3 \%$. The oxygen isotopic composition of foraminiferal carbonate (10 specimens of the $125-250 \mu \mathrm{m}$ fraction of the planktonic $N$. pachyderma per sample) was determined by a Finnigan MAT 251 mass spectrometer using standard techniques.

For the determination of lipids, freeze-dried and gently ground subsamples $(\sim 2 \mathrm{~g})$ were extracted by successive sonication and centrifugation in methanol, methanol:methylene chloride $(1: 1)$, and methylene chloride, respectively. The extracts were saponified $(6 \% \mathrm{KOH})$, further extracted with hexane, and derivatized with BSTFA (Sigma) prior to injection onto a HP1 chromatographic column $(50 \mathrm{~m}$ length, $0.32 \mathrm{mminside}$ diameter, $0.17 \mu \mathrm{m}$ film thickness).

Lignın-derived phenols were determined by gas chromatography-flame ionization detection of the trimethylsilyl derivatives following $\mathrm{CuO}$ oxidation of bulk samples under alkaline conditions [Hedges and Ertel, 1982].

\section{Stratigraphy}

Stratigraphy of the cores is based on a correlation of the oxygen isotope profiles as well as accelerator mass spectrometry (AMS) ${ }^{14} \mathrm{C}$ dates (Table 2 and Figure 2) [Stein et al., 1994a, Nørgaard-Pedersen, 1996; Nørgaard-Pedersen et al., 1998]. Core PS2185-4 was correlated with PS2185-3 (box-core from the same position), and core PS2178-4 was correlated with PS2180-1 (nearby box-core from $87^{\circ} 37.6^{\circ} \mathrm{N}$, $156^{\circ} 40.5^{\circ} \mathrm{E}, 4005 \mathrm{~m}$ water depth). TOC and carbonate concentrations and planktonic foraminifera content were used for correlation as well as the foraminiferal oxygen and carbon isotope data. With the present age model it is not clear whether the lowermost parts of core PS2170 actually reach into isotopic stage 4 or only represent the oldest stage 3 . Core PS2 178 with a length of $32 \mathrm{~cm}$ might have recovered stage 5 sediments in the lowermost part since the stage $2 / 3$ boundary occurs at $10 \mathrm{~cm}$ depth.

Sedimentation rates in the Arctic Ocean are generally very low [Sejrup et al., 1984; Stein et al., 1994a]. During Termination I they varied between 0.7 and $0.8 \mathrm{~cm} / \mathrm{kyr}$ for the Gakkel and Lomonosov Ridge's, and the Amundsen Basin; a lower rate of $0.4 \mathrm{~cm} \mathrm{kyr}^{-1}$ was determined for the Makarov Basin core. Holocene sedimentation rates are 0.6 and $0.7 \mathrm{~cm}$ $\mathrm{kyr}^{-1}$ for the Makarov Basin and Gakkel Ridge and slightly higher $\left(0.9 \mathrm{~cm} \mathrm{kyr}^{-1}\right)$ for the Lomonosov Ridge and the Amundsen Basin [cf. Stein et al., 1994a]. Overall, sedimentation rates in the central Arctic Ocean during specific stages appear to be relatively constant; however, glacial values are somewhat lower and then increase during the transition (Termination I) and into the Holocene [cf. Steln et al., 1994a].

Table 2. AMS ${ }^{14} \mathrm{C}$ Ages for Selected Samples of Cores PS2163-1, PS2170-4, PS2185-4, and PS2180-1

\begin{tabular}{|c|c|c|c|c|}
\hline & $\begin{array}{l}\text { Depth } \\
\text { cmbsf }\end{array}$ & $\begin{array}{c}\text { Age } \\
{ }^{14} \mathrm{C} \text { Reservoir Corrected }\end{array}$ & $\begin{array}{l}\text { Age } \\
\text { Calendar }\end{array}$ & $\begin{array}{l}\text { Corresponding Depth } \\
\text { cmbsf }\end{array}$ \\
\hline PS2163-1 & 3.5 & $4750 \pm 80$ & 3620 to 3530 & \\
\hline PS2163-1 & 9.5 & $14490 \pm 140$ & 15410 & \\
\hline PS2163-1 & 22.5 & $>41000$ & & \\
\hline PS2163-1 & 25.5 & $>38000$ & & \\
\hline PS2 170-4 & 6.5 & $7190 \pm 90$ & 6000 & \\
\hline PS2170-4 & 13.5 & $15710 \pm 180$ & 16650 & \\
\hline PS $2170-4$ & 18.5 & $36950 \pm 900$ & & \\
\hline PS2170-4 & 23.5 & $34150 \pm 600$ & & \\
\hline PS2185-3 & 4.5 & $5290 \pm 60$ & 5720 & $3.0^{\mathrm{b}}$ \\
\hline PS2 185-3 & 7.5 & $7975 \pm 75$ & 9050 & $7.0^{\mathrm{b}}$ \\
\hline PS2185-3 & 11.5 & $13950 \pm 160$ & 16460 & $12.0^{\mathrm{b}}$ \\
\hline PS2 $185-3$ & 14.5 & $23250 \pm 230$ & 27350 & $14.0^{\mathrm{b}}$ \\
\hline PS2185-3 & 16.5 & $30380 \pm 530$ & 35020 & $15.0^{\mathrm{b}}$ \\
\hline PS2185-3 & 19.5 & $33670 \pm 550$ & 38360 & $18.0^{\mathrm{b}}$ \\
\hline PS2180-1 & 4.5 & $6860 \pm 130$ & 7666 & $4.0^{\mathrm{c}}$ \\
\hline PS2180-1 & 6.5 & & & $6.0^{\mathrm{c}}$ \\
\hline PS2180-1 & 8.5 & $15830 \pm 150$ & 18789 & $8.0^{c}$ \\
\hline PS2180-1 & 12.5 & $34620 \pm 800$ & 39303 & $12.0^{\mathrm{c}}$ \\
\hline PS2180-1 & 14.5 & $36950 \pm 970$ & 41566 & $13.0^{\mathrm{c}}$ \\
\hline PS2180-1 & 17.5 & & & $14.0^{\mathrm{c}}$ \\
\hline PS2180-1 & 19.5 & & & $17.0^{c}$ \\
\hline
\end{tabular}

${ }^{a}$ Core PS2 180-1 is located very close to PS2178-4. Shown are the accelerator mass spectrometry (AMS) ${ }^{14} \mathrm{C}$ and calendar ages as well as the corresponding depths of the correlated cores (cmbsf, centımeter below seafloor).

${ }^{b}$ Corresponding to core PS2185-4

${ }^{c}$ Corresponding to core PS2178-4 


\section{Oxygen stable isotopes (\% vs.PDB)}
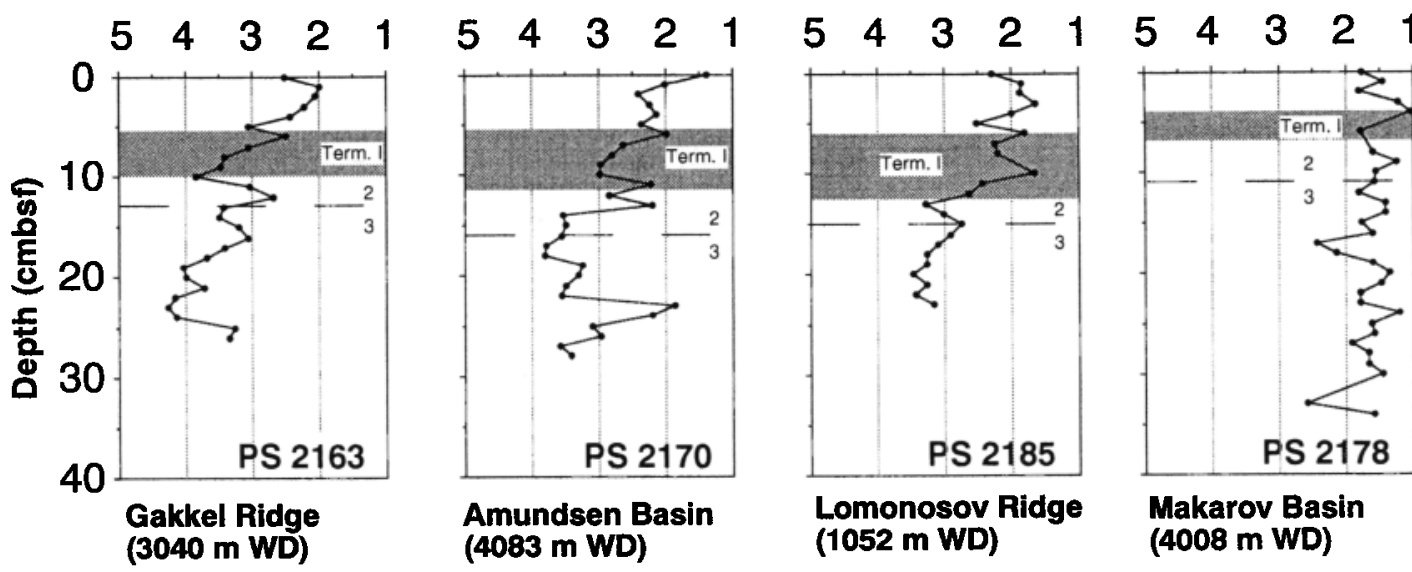

\section{Carbon stable isotopes (\%॰ vs. PDB)}
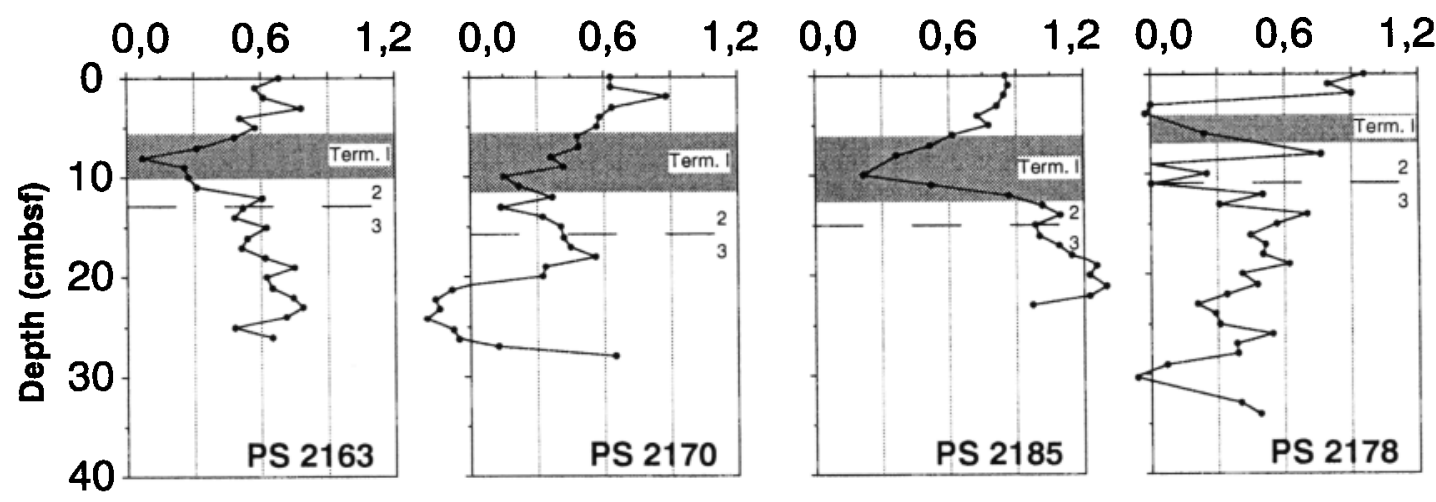

Figure 2. Oxygen and carbon stable isotope ratios in per mil pee dee blemnite (PDB) of the four multicorer cores (WD, water depth; cmbsf, centimeters below seafloor).

\section{Environmental Setting}

The Arctic Ocean is unique among the oceans of the world in that $49 \%$ of its area is relatively shallow, primarily the wide European and Siberian shelves [Johnson, 1990]. Water exchange with other oceans today mainly occurs through the Fram Strait, with water depths of up to $2600 \mathrm{~m}$, and through Barents Sea, which is up to $250 \mathrm{~m}$ deep [Rudels et al., 1994; Schauer et al., 1995]. The Bering Strait is only $200 \mathrm{~m}$ deep and plays a minor role in water exchange [Curtin et al., 1990]. During the Last Glacial Maximum (LGM), however, the deep Fram Strait was the only connection. Two major oceanographic current systems dominate the Arctic Ocean: (1) the Transpolar Drift, which influences our core positions, transports sea ice from the Siberian shelf through the central Arctic Ocean to the Fram Strait, and (2) the cyclonic Beaufort Gyre in the Amerasian Basin that probably influences only the Makarov Basin core.

Another important feature of the Arctic Ocean is its yearround sea ice cover with a strong seasonal variation in coverage of the marginal shelf areas. Sea ice cover restricts surface productivity owing to low light influx into the surface waters. For example, only $0.1 \%$ of incident light penetrates snow and ice (assuming $8 \mathrm{~cm}$ of snow on $3.5 \mathrm{~m}$ of sea ice) to reach the surface water [Andersen, 1989]. Estimates of primary production in the Arctic Ocean are very sparse; in general, very low values characterize the central area, the region where our cores are located (e.g., $0.09 \mathrm{~g} \mathrm{C} \mathrm{m}^{-2} \mathrm{day}^{-1}$ ) [Wheeler et al., 1996], whereas much higher values have been obtained in the marginal zones, such as the shelves and coastal fjords [Subba Rao and Platt, 1984]. Values off Svalbard vary between 0.43 and $0.89 \mathrm{~g} \mathrm{C} \mathrm{m}^{-2}$ day $^{-1}$ [Heimdal, 1983], whereas in the Fram Strait values show a wide range from 0.059 to $1.067 \mathrm{~g} \mathrm{C} \mathrm{m}^{-2}$ day $^{-1}$ which strongly correlates with the extent of sea ice cover [Hirche et al., 1991]. In this context, today, nutrients are severely depleted at polynyas and ice edge regimes [Hirche et al., 1991], whereas in the central Arctic Ocean a severe seasonal nutrient depletion was not observed in summer 1996 [Wheeler et al., 1996].

Previous investigations have shown a significant influence of sea ice on sedimentation in the Arctic Ocean [Reimnitz and Kempema, 1987; Reimnitz and Saarso, 1991; Wollenburg, 1993; Nürnberg et al., 1994]. Large amounts of sediment entrained into sea ice on the shallow Arctic shelves, material which derives in large part from the Arctic river systems and therefore contains high amounts of terrestrial organic material 
[Aargaard and Carmack, 1989; Stein, 1998] as well as organic material that has been produced on the shelves during bloom events associated with the receding ice edge are transported by surface currents over the Arctic Ocean and released during melt processes [Wollenburg, 1993]. An additional source of shelf material in the central Arctic is density or turbidity currents recorded in sediment sequences sampled on the slopes and in the basins [Fütlerer, 1992, 1994].

\section{Results}

The $\delta^{15} \mathrm{~N}$ values of the multicorers range between 2.8 and $6.8 \%$, with very similar values $(\sim 6.2 \%)$ at the surface $(1-2 \mathrm{~cm})$ of the northernmost three cores (PS2170, PS2185, and PS2178, Figure 3). Variations in core PS2163-1 from the Gakkel Ridge are smaller and range from 3.4 to $6 \%$; here the two surface values are slightly lower (5.7 and 5.4\%) than those in the other core tops. All profiles are quite similar in that values lie around $3.4-5 \%$ in lower oxygen isotope stage (OIS) 3 (the lowermost samples of cores PS2170 and PS2178 may actually represent OIS 4 but could not be distinguished as mentioned above), decreasing to minimal values of $2.8-4 \%$ in upper OIS 3 and lower OIS 2 and then increasing continuously from the upper part of isotope stage 2 to the sediment surface. Core PS2170 from the Amundsen Basin shows slightly higher nitrogen isotope values at the OIS $2 / 3$ transition that decline briefly at Termination $I$ and then increase steadily to the core surface. The abrupt change in core PS2178-4 at $25 \mathrm{~cm}$ depth coincides with a similar abrupt change in the TOC profile. Carbon isotope ratios of the organic matter in the cores range from -20.8 to $-23.6 \%$. The lightest value is found in the Gakkel Ridge core (PS2163), and the heaviest value occurs in the core from the Lomonosov Ridge (PS2185), maybe as a result of lower terrestrial input (no turbidity current influence) on the top of the ridge. Values are highest at the core tops and decrease down core, increasing again below Termination I (PS2170, PS2185, and PS2178) or in OIS 3 (PS2163). In general, carbon isotope values follow the nitrogen isotope values very closely, with minor excursions in the lower part of core PS2185 and the middle part of core PS2 $178\left(r^{2}=0.70\right.$, PS2 $163 ; r^{2}=0.90$, PS $2178 ; r^{2}$ $=0.68$, PS2 170; and $r^{2}=0.66$, PS2 185). TOC concentrations range from 0.1 to $0.7 \%$, highest values occurring at the core tops (Figure 3 ). The up core increase in organic carbon starts at $\sim 5 \mathrm{~cm}$ in cores PS2 163 and PS2178 and at $\sim 10 \mathrm{~cm}$ in cores PS2170 and PS2185. In general, there is a high correlation between the organic carbon content and the nitrogen isotope ratios in all four cores $\left(r^{2}=0.68\right.$, PS2 $163 ; r^{2}=0.88$, PS2178; $r^{2}=0.91$, and PS2170; $r^{2}=0.95$, PS2185). Stein et al. [1994b] and Schubert and Stein [1997] showed that organic carbon in the Arctic Ocean includes relatively large proportions of terrestrial organic matter. Sea ice or gravitational transport of this material from the shelf areas with high river input (e.g. Laptev Sea and Kara Sea shelves), as mentioned above, is responsible for this distribution. This has to be taken into account when using the organic carbon concentration to interpret productivity changes in the Arctic Ocean. However, recent data based on isotopic and organic geochemical investigations suggest a maximum of $30 \%$ contribution of terrestrial organic carbon in surface sediments of the central Arctic Ocean [Schubert and Calvert, 2001], a contribution that is significantly less than previously assumed [Stein et al., 1994b; Schubert and Stein, 1997]. Carbonate concentrations (Figure 3 ) are generally $<8 \%$; only core PS2185-4 shows higher values of up to $14 \%$. It was shown by Nørgaard-
Pedersen [1996] and Vogt [1997] that a significant proportion of the carbonate in the cores from the eastern central Arctic Ocean may consist of detrital calcite, magnesian calcite, and dolomite that was transported by sea ice and glaciers from the surrounding continents. However, in almost all cores, biogenic carbonate (mainly planktonic foraminifera) forms a significant proportion of the carbonate profile [Stein et al, 1992; Schubert, 1995]; only the carbonate peak during Termination I in cores PS2178-4 and PS2185 represents mainly ice rafted detrital material [Norgaard-Pedersen, 1996; Nørgaard-Pedersen et al., 1998].

\section{Discussion}

It has been shown earlier that nitrogen isotopic values of surface sediments in the Arctic Ocean provide information on the spatial variations in nutrient utilization in the surface water that are linked to changes in productivity [Schubert and Calvert, 2001]. Whereas measured nitrate values in the surface layer (upper $30 \mathrm{~m}$ ) [Leif Andersen, University of Göteborg, unpublished data, 1997] decrease from the inflow into the Arctic Ocean close to Svalbard toward the central Arctic Ocean, the $\delta^{15} \mathrm{~N}$ values of the underlying sediments increase along the same path (Figures $4 \mathrm{a}$ and $4 \mathrm{~b}$ ). This signal has been interpreted as variations in relative nitrate utilization in various regions of the Arctic Ocean, i.e., lower nutrient utilization at higher nutrient concentrations in the south and higher nutrient utilization at lower nutrient concentrations in the north [Schubert and Calvert, 2001]. In the following discussion we use the information on surface sediments to examine the possible reasons for the clear temporal changes in sedimentary nitrogen and carbon isotopic ratios in Arctic Ocean sediments covering approximately the last 50,000 years in terms of variations in nutrient utilization and hence production and changes in $\mathrm{pCO}_{2}$ of surface waters. Apart from the Makarov core (PS2178), the distinctive feature of our core profiles is the apparent parallel variations of the nitrogen and carbon isotope ratios. There are several possible reasons for this concordance: (1) the isotopic values reflect a variable contribution of terrestrial and marine organic material to the sediments; (2) nitrogen isotope ratios increase due to higher nutrient utilization by the phytoplankton in surface waters while the heavier carbon isotopic composition of a sample reflects the higher contribution of marine organic matter; that is, there was a higher productivity in the surface waters; (3) nitrogen isotope ratios in the sediment increase owing to higher nutrient utilization of the phytoplankton in surface waters, and the organic carbon isotopic composition is related to changes in the $p \mathrm{CO}_{2}$ of the surface waters and/or other factors (phytoplankton growth rate, species composition, and cell surface to volume ratio) that have been identified to influence organic carbon isotopic composition [Rau et al., 1997; Laws et al., 1995].

\subsection{Marine Source Signal}

Marine phytoplankton uses mainly nitrate or, in nitratedepleted waters, ammonium as the fixed nitrogen source. During the assimilation process the lighter isotope ${ }^{14} \mathrm{~N}$ is preferentially used over the heavier ${ }^{15} \mathrm{~N}$, which leads to lighter $\delta^{15} \mathrm{~N}$ plankton values compared to the substrate [Wada and Hattori, 1978; Mariotti et al., 1981]. If nitrate uptake occurs with a constant isotope effect and if the surface ocean receives no new nitrate over the course of seasonal nitrate uptake, then this process can be described in terms of Rayleigh 

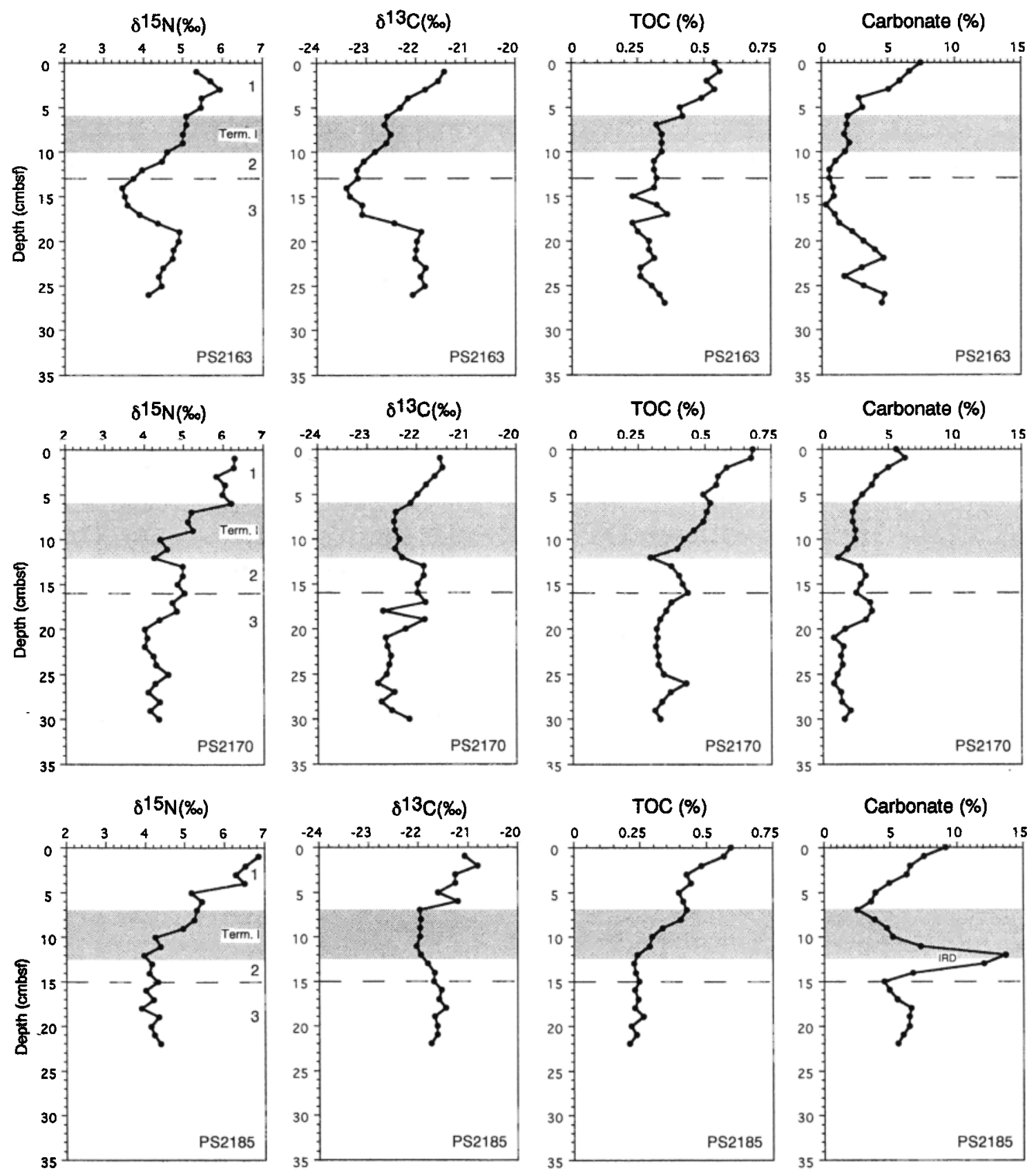

Carbonate (\%)
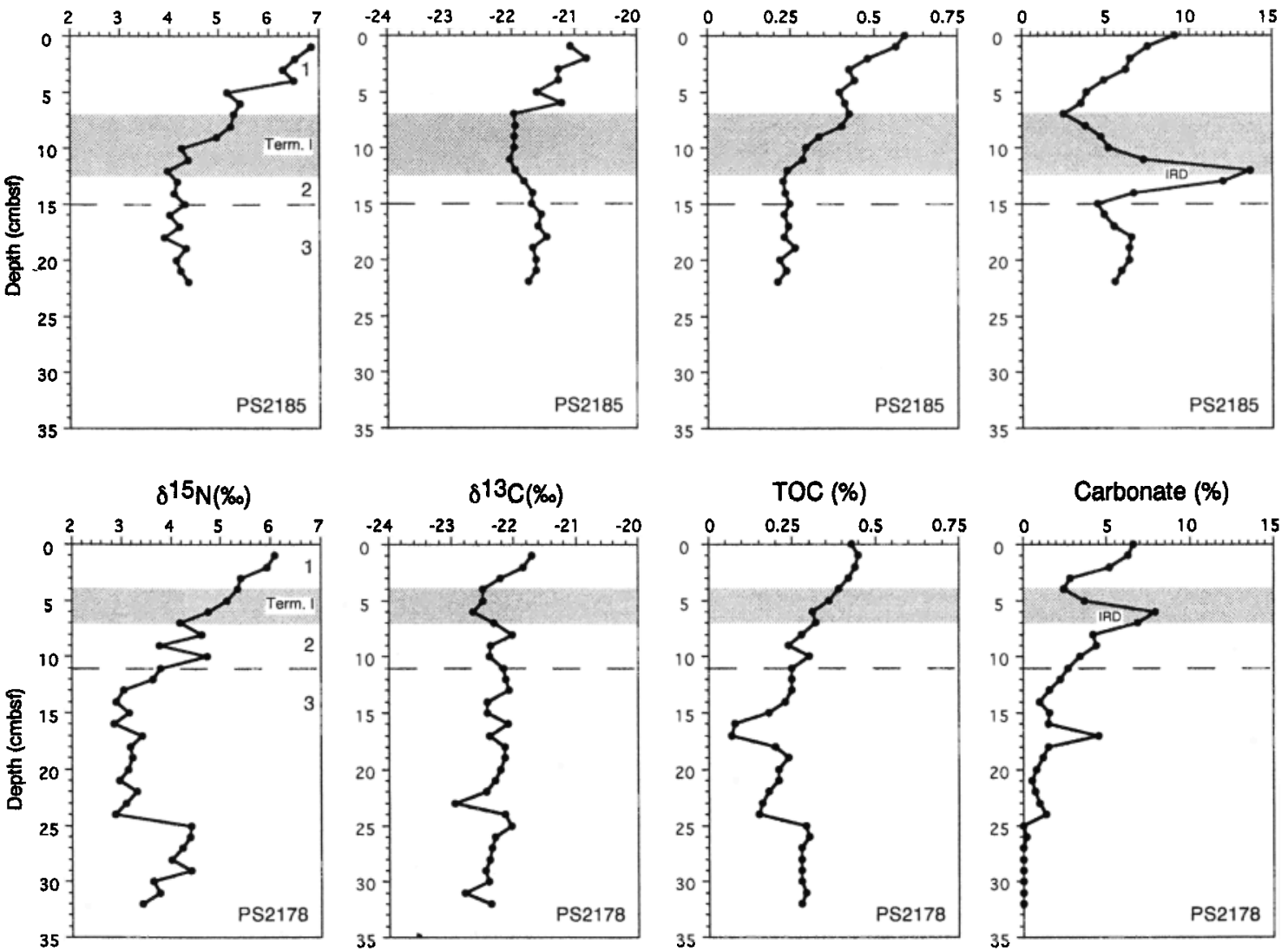

Figure 3. Nitrogen and carbon isotope ratios (in per mil) versus air and PDB, respectively, organic carbon (TOC), and carbonate concentration (in percent) of the four multicorer cores. 

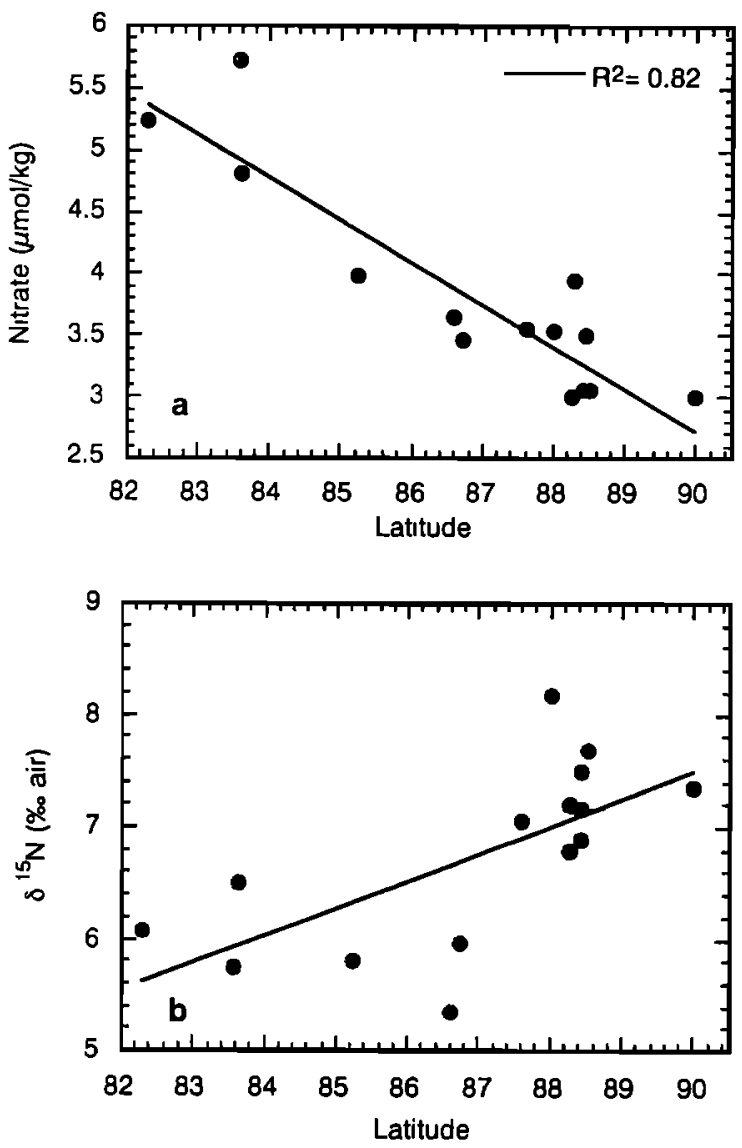

Figure 4. (a) Nitrate concentrations in the upper $30 \mathrm{~m}$ water column of Arctic surface water plotted against latitude (Leif Andersen, University of Göteborg, unpublished data, 1997).

(b) The $\delta^{15} \mathrm{~N}$ values of surface sediments of the central Arctic Ocean. Note the strong inverse correlation between nitrate in the surface water (Figure 4a) and the $\delta^{15} \mathrm{~N}$ values of the underlying sediments (Figure 4b). Reprinted from DSR I, 48, Schubert and Calvert, Nitrogen and carbon isotopic composition of marine and terrestrial organic matter in Arctic Ocean sediments: implications for nutrient utilization and organic matter composition, 789810,2000 , with permission from Elsevier Science.

fractionation kinetics [Mariotti et al., 1981]. During consumption of the nitrate reservoir the isotopic variation of nitrate is then defined by (1), the instantaneously generated organic $\mathrm{N}$ is defined by (2), and the integrated organic $\mathrm{N}$ pool is defined by (3):

$\delta^{15} \mathrm{NO}_{3}{ }^{-}=\delta^{15} \mathrm{NO}_{3}^{-}{ }_{\text {inital }}-\varepsilon\left\{\ln \left(\left[\mathrm{NO}_{3}^{-}\right] /\left[\mathrm{NO}_{3}{ }^{-}\right]_{\text {inttal }}\right)\right\}$,

$\delta^{15} \mathrm{~N}_{\text {Ins! }}=\delta^{15} \mathrm{NO}_{3}^{-}-\varepsilon$,

$\delta^{15} \mathrm{~N}_{\mathrm{Im}}=\delta^{15} \mathrm{NO}_{3}^{-}{ }_{\text {initial }}+\varepsilon\left\{\left[\mathrm{NO}_{3}{ }^{-}\right] /\left(\left[\mathrm{NO}_{3}{ }^{-}\right]_{\text {inltal }}-\left[\mathrm{NO}_{3}{ }^{-}\right]\right)\right\}$ $\ln \left(\left[\mathrm{NO}_{3}^{-}\right] /\left[\mathrm{NO}_{3}{ }^{-}\right]_{\text {milıal }}\right)$,

$\delta^{15} \mathrm{~N}$ values of recent surface sediments vary from 1 to $16 \%$ as measured in the North Atlantic [Altabet and McCarthy, 1985; Altabet et al., 1991], the Southern Ocean [Francois et al., 1992; Altabet and Francois, 1994b], the central [Altabet and Francois, 1994b] and eastern [Farrell et al., 1995] equatorial Pacific, the Angola Basin [Holmes et al., 1996], and the
Benguela Current region [Holmes et al., 1998] and in the South China Sea [Kienast, 2000]. In these studies most of the lowest values (below $4 \%$ ) come from the Southern Ocean where nutrients are less depleted. Similar values for this region have been measured by Sigman et al. [1999a] on bulk organic matter; measured values of diatom-bound organic matter are even lower.

Another source of isotopically light planktonic organic matter, mainly in tropical regimes, is nitrogen fixation by cyanobacteria [Carpenter, 1983; Carpenter and Romans, 1991; Capone et al., 1997]. These organisms fractionate nitrogen isotopes to a very small extent; $\delta{ }^{15} \mathrm{~N}$ values close to atmospheric nitrogen ( $\pm 0 \%$ ) therefore result [Carpenter et al., 1997]. This process, however, is very unlikely to be significant in near-freezing Arctic surface waters.

We have previously shown that the nitrogen isotopic composition of surface sediments becomes progressively heavier on a transect from the area north of Svalbard to the center of the Arctic Ocean [Schubert and Calvert, 2001]. A clear inverse correlation between increasing $\delta^{15} \mathrm{~N}$ values in underlying surface sediments and decreasing nitrate concentrations in the surface waters flowing from the Atlantic into the Arctic through the Fram Strait and the Barents Sea is related to higher nutrient utilization in the central Arctic. In the work of Schubert and Calvert an $\varepsilon_{\mathfrak{u}}$ (fractionation factor of phytoplankton) of $7.2 \%$ was determined from the sedimentary isotope data, a value that lies well within the range of previously published values of $0.3-23 \%$ [Montoya, 1994] and compares well with values of $8 \%$ and $9 \%$ from the Weddell Sea and the subarctic Pacific, respectively [Biggs et al., 1988; Altabet and Francois, 1994b]. However, more recently, a nitrate uptake effect in Antarctic waters of $5 \pm 1 \%$ has been reported from water column data [Sigman et al., 1999b]. This is a more direct measure of the link between nitrate utilization and nitrogen isotopes compared with estimates based on particulate and sedimentary $\delta^{15} \mathrm{~N}$; we therefore adopt a value of $5 \pm 1 \%$ for phytoplanktonic nitrate uptake in this paper.

\subsection{Terrestrial Influences}

Land-derived organic material is depleted in ${ }^{15} \mathrm{~N}$ since the metabolism used by land plants is nitrogen fixation with low isotopic fractionation [Miyaka and Wada, 1967] which leads to low $\delta^{15} \mathrm{~N}$ values. This is consistent with results reported by Wada et al. [1987b], who showed that land plants had $\delta^{15} \mathrm{~N}$ values of $-1.8 \pm 0.8 \%(n=7)$, detrital organic matter in a river had values of $2.8 \pm 0.1 \%(n=3)$, and soil organic matter had values of $4.1 \pm 0.4 \% 0(n=4)$. The $\delta^{15} \mathrm{~N}$ values of POM of an upper estuary and lakes in Scotland showed values around 3.7 $\pm 1.1 \%(n=5)$ and $1.9 \pm 1.7 \% 0(n=8)$, respectively [Thornton and McManus, 1994]. Naidu et al. [2000] report $\delta^{15} \mathrm{~N}$ values of Mackenzie River sediment samples ranging between 1.4 and $2.8 \%$. However, $\delta^{15} \mathrm{~N}$ values $(2.8$ and $8 \%$ ) on dust particles off the west coast of Africa (Gaute Larvik, personal communication., 2000), in Africa vegetation (-1-6\%) [Heaton, 1987], and in various leaves and soils of tropic and temperate regions (-10.1-13.3\%) [Martinelli et al., 1999] have been measured indicating that there is a wide $\delta^{15} \mathrm{~N}$ range for terrestrial derived organic material.

Schubert and Calvert [2000] have shown that the terrestrial influence in central Arctic Ocean surface sediments might be as high as $30 \%$ based on estimates of the organic carbon isotopic composition and taking the different sources (river input, 
surface water plankton, ice algae plankton) into account. By using different indicators for organic matter composition we estimate whether the contribution of terrestrial organic matter has been constant over the time period represented in our cores and if changes in the contribution of terrestrial organic matter have influenced the nitrogen isotopic signal.

We determined selected biomarker concentrations in PS2170 to search for information on the relative importance of landderived organic matter in Arctic Oceans sediments. We extrapolate these results to all four cores in view of the close similarity of the down core profiles of $\delta^{15} \mathrm{~N}, \delta^{13} \mathrm{C}$, and TOC.

Lignin is a unique indicator of organic matter derived from terrestrial higher plants [Leo and Barghorn, 1970], and its distribution in marine sediments has widely been used to reconstruct terrestrial influences on sediment deposition [e.g., Hedges and Parker, 1976; Prahl et al., 1994]. Lignin concentrations $\lambda$ in three samples of core PS2170 are low and relatively constant, ranging between 0.033 and $0.043 \mathrm{mg} 100$ $\mathrm{mg}^{-1}$ OC (Table 3). A similar value $\left(0.043 \mathrm{mg}^{100 \mathrm{mg}^{-1}} \mathrm{OC}\right)$ was obtained in core PS 2185 in $10.5 \mathrm{~cm}$ depth. Although we have only a few measurements, these values imply a relatively small but constant terrestrial contribution to our core sites over glacial-interglacial timescales.

Long-chain $n$-alkanes with an odd carbon number dominance occur in high concentration in leaf waxes from land plants [Eglinton and Hamilton, 1963]. They are not known to occur (i.e., with an odd-over-even predominance) in marine organisms and therefore are a reliable indicator in environmental and paleoenvironmental studies [Reddy et al., 2000]. They have been widely used as indicators of terrestrial organic matter input in sediments [Prahl and Muehlhausen, 1989; Prahl et al., 1994; Schubert and Stein, 1996, 1997]. Long-chain $n$-alkane concentrations of 204-821 $\mu \mathrm{g} \mathrm{g}^{-1} \mathrm{OC}$ (average $430 \mathrm{\mu g} \mathrm{g}^{-1} \mathrm{OC}$, Table 3 ) were found in core 2170 , concentrations that are in the range of values measured on the Laptev Sea shelf and slope, although there extreme concentrations of up to $\sim 1400 \mu \mathrm{g} \mathrm{g}^{-1}$ OC occur [Fahl and Stein, 1997]. Although the variability of the alkane concentrations is rather high, there is a very poor correlation with both the carbon isotopic values $\left(r^{2}=0.10\right)$ and the nitrogen isotopic values $\left(r^{2}=0.25\right.$, Figure 5$)$, suggesting that changes observed in either nitrogen or carbon isotopes are not related to variable contributions of terrestrial organic matter. We therefore conclude that although we have a higher input of terrestrial organic material and frequent changes thereof (based on the $n$-alkane data) in Arctic Ocean sediments compared to other oceans, changes in these contributions have not occurred simultaneously with changes in $\delta^{15} \mathrm{~N}$ and $\delta^{13} \mathrm{C}$ (i.e. on a glacial-interglacial timescale).

This implies that although the transport mechanisms for terrestrial organic matter between the last glacial and the termination and the Holocene have changed significantly, the contribution of terrestrial organic material was rather constant. Low sea level and exposed shelves during the LGM hindered sediment entrainment by sea ice. On the other hand, during this time, rivers cut into the shelves and carried their sediment load directly into the deep basin. During the Holocene, on the other hand, river sediment load first accumulates on the shelves and is then entrained into sea ice and transported into the ocean basins.

\subsection{Effects of Diagenesis and Denitrification}

The nitrogen isotopic composition of sedimentary organic matter is known to be affected to variable extents by diagenetic effects both in the water column and on the seafloor. Possible diagenetic alterations have been discussed in detail by Altabet and Francois [1994b], Altabet et al. [1999], and

Table 3. Long-Chain $n$-Alkane and Lignin Concentrations of Samples of Cores PS2170-4 and PS2185-4

\begin{tabular}{|c|c|c|c|}
\hline $\begin{array}{c}\text { PS2170, } \\
\mathrm{cm}\end{array}$ & $\begin{array}{c}\mathrm{C}_{27}+\mathrm{C}_{29}+\mathrm{C}_{31} \\
\mathrm{ug} \mathrm{kg}\end{array}$ & $\begin{array}{c}\mathrm{C}_{27}+\mathrm{C}_{29}+\mathrm{C}_{31} \\
\mathrm{ug} \mathrm{g}^{-1} \mathrm{OC}\end{array}$ & $\begin{array}{c}\lambda \\
\mathrm{mg} 100 \mathrm{mg}^{-1} \mathrm{OC}\end{array}$ \\
\hline 1.5 & 1845 & 275 & \\
\hline 2.5 & & & 0.046 \\
\hline 35 & 2849 & 518 & \\
\hline 5.5 & 1438 & 288 & \\
\hline 7.5 & 2400 & 471 & \\
\hline 85 & & & 0.046 \\
\hline 95 & 1908 & 415 & \\
\hline 115 & 2022 & 506 & \\
\hline 13.5 & 1293 & 349 & \\
\hline 15.5 & 855 & 204 & \\
\hline 17.5 & 3037 & 821 & \\
\hline 19.5 & 1162 & 352 & \\
\hline 21.5 & 1044 & 326 & \\
\hline 23.5 & 1655 & 517 & \\
\hline 255 & 1283 & 377 & \\
\hline 26.5 & & & 0.033 \\
\hline 27.5 & 1280 & 346 & \\
\hline 29.5 & 2048 & 661 & \\
\hline \multicolumn{4}{|l|}{$\begin{array}{l}\text { PS2185, } \\
\text { cm }\end{array}$} \\
\hline 10.5 & & & 0.043 \\
\hline
\end{tabular}




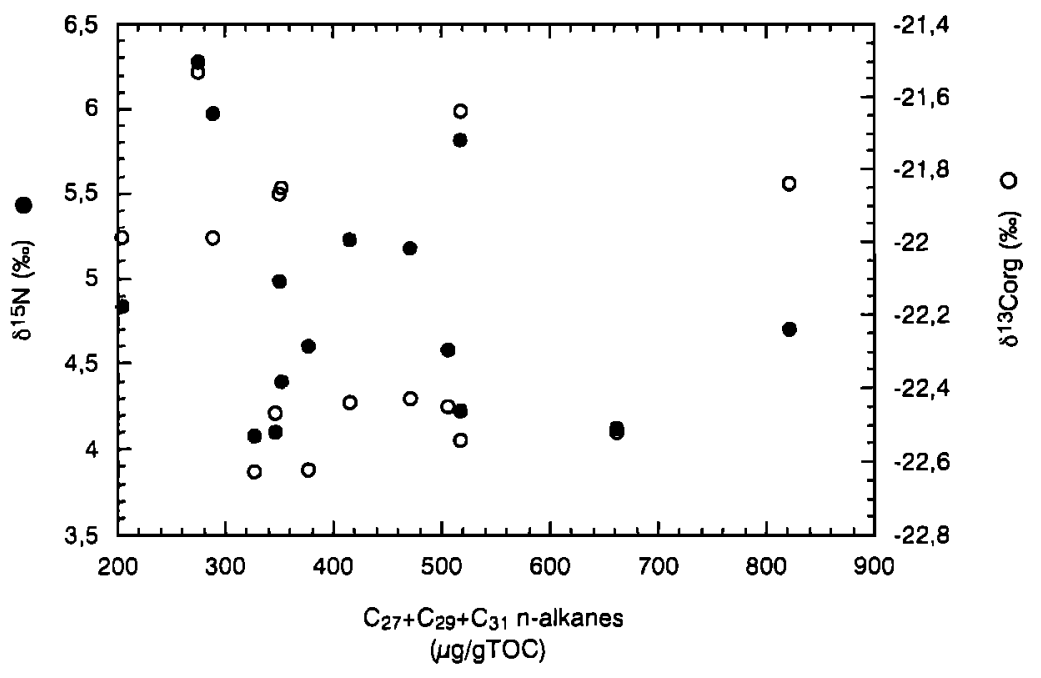

Figure 5. Correlation between $\delta^{13} \mathrm{C}_{\text {org }}$ and $\delta^{15} \mathrm{~N}$ values with the long-chain $n$-alkane concentrations in core PS2170. Correlation factors are 0.10 and 0.25 , respectively.

Kienast [2000]. Whereas in coastal, high sedimentation rate settings the isotopic signal generated in the surface waters is reliably transferred to and preserved in the sediments, slowly accumulating sediments in the Southern Ocean and the equatorial Pacific appear to be 4-5\% enriched in $\delta^{15} \mathrm{~N}$ sinking particles [Altabet and Francois, 1994b; Biggs et al., 1988]. Since sedimentation rates in the Arctic Ocean ate of the same order of magnitude as those in the central Pacific and the Southern Ocean, it is reasonable to assume a similar diagenetic effect on the sedimentary $\delta^{15} \mathrm{~N}$ observed. In the absence of sediment trap data from this region, we therefore adopt a diagenetic effect of 4-5\%.

In spite of the relatively large change in $\delta^{15} \mathrm{~N}$ during particle settling in the deep equatorial Pacific, Altabet and Francois [1994b] found very small changes in the isotopic composition of sedimentary organic matter in the uppermost $2 \mathrm{~cm}$ of cores, although there was a decrease in nitrogen with depth of $\sim 30 \%$. Sigman et al. [1999a] found a gradual decrease of nitrogen isotope values with decreasing nitrogen content in Southern Ocean cores. It appears that the nitrogen isotopic signal, once it has been incorporated into the sediment, undergoes fairly small changes during burial. In the case of the Arctic Ocean sediments, any diagenetic overprint would be accentuated in the LGM sediments where nitrogen contents are low. Our suggestion that there was a lower nitrate drawdown (see below) is therefore conservative. The basin-wide signal of changes in nitrogen as well as carbon isotope ratios in the cores studied here shows that a diagenetic influence at each of the core positions was probably similar.

Severe enrichments $(8-12 \%)$ in sedimentary nitrogen isotopic composition have also been observed in regions of significant water column denitrification, as observed in some continental margin regimes where oxygen minima are especially intense [Ganeshram et al., 1995; Altabet et al., 1999]. Denitrification in the modem well-oxygenated water column of the Arctic Ocean is absent and should not have affected the sedimentary nitrogen isotopic signal. During the LGM an intense sea ice cover might have reduced ventilation of the water column; if denitrification occurred, we would expect to find higher $\delta^{15} \mathrm{~N}$ values during these times, which are not observed.

\subsection{Palaeoceanographic Interpretation of the Isotopic Records}

After discussing the different factors that might influence the nitrogen isotope record in sediments, we will now try to interpret the profiles of nitrogen and carbon isotope ratios as well as TOC and carbonate concentration in our cores. As mentioned previously, organic carbon values not only reflect the presence of marine organic material but also that of terrestrial material. However, the biomarker data suggest that there is a small and constant terrestrial background signal on which the marine signal is superimposed. Apart from the two peaks marked ice-rafted debris (IRD) in Figure 3, the carbonate fraction of the cores is mainly composed of planktonic foraminifera and therefore monitors marine production. We will first concentrate on interpreting the profiles from the uppermost part of OIS 3 to the Holocene since here age control is supported by AMS ${ }^{14} \mathrm{C}$ dates. Low $\delta^{15} \mathrm{~N}$ values $(3-4 \%$ ) are observed in all four cores in the uppermost part of OIS 3 and in OIS 2; values in PS2170 are slightly higher during this period but still lower than at the core top. These values coincide with low TOC and low biogenic carbonate concentrations. As concluded earlier by Norgaard-Pedersen et al. [1998], low sedimentation rates, low planktonic productivity, and low IRD contents during OIS 2 and late OIS 3 indicate a closely packed sea ice cover. This is in good agreement with the low nitrogen isotope values during that time interval, indicating very low nutrient utilization. During this period we deal with a central Arctic Ocean that was almost completely covered by sea ice. Production of phytoplankton was very low due to low light conditions under the ice as indicated by low organic carbon content that might represent only the background terrestrial organic material. The water column, today represented by a lowdensity surface water layer (50-200 m) separated from deeper water layers [Anderson et al., 1994; Rudels et al., 1994], was most likely not stratified. The reason for this is that processes that are responsible for the low-salinity layer today, like brine formation during sea ice formation in winter, sea ice melting, and high river input in summer, were much reduced during the LGM. The low nitrogen isotope signal in the sediments therefore most likely records low stratıfication of the water 
column which facilitates exchange with the deepwater nitrate source. Assuming the same $\delta^{15} \mathrm{~N}$ deep water value (4.6-4.8\%) [Sigman et al., 1999b, 2000] as prevailing today, the sinking phytoplankton would have a very light $\delta^{15} \mathrm{~N}$ value due to low production in nutrient replete waters $(\sim 0 \pm 1 \%$, assuming a fractionation factor $\varepsilon$ of $4-5 \%$ during nitrate uptake [Sigman et al., 1999a]). During settling through the water column diagenesis will give a 4-5\% overprint [Altabet and Francois, $1994 \mathrm{~b}]$, a $\delta^{15} \mathrm{~N}$ value that we actually observe in the cores. Rau et al. [1982] showed that the carbon isotope ratios in plankton become lighter with increasing latitude in the Southern Ocean and in the northern North Atlantic, a signal that has been explained by the higher solubility of carbon dioxide in colder surface waters. Accordingly, if this trend proceeds into the Arctic Ocean, surface water will become enriched in carbon dioxide as long as it is in contact with the atmosphere, i.e., if no sea ice cover exists. Under low phytoplankton production a depletion of carbon dioxide in the water column could be excluded, and relatively light $\delta^{13} C_{\text {org }}$ values like those observed in the cores profiles should result. Other work on phytoplankton cultures has indicated that processes other than $p \mathrm{CO}_{2}$ (e.g., phytoplankton growth rate, species composition, cell surface to volume ratio or light) can also affect the carbon isotopic composition of planktonic organic matter [Thompson and Calvert, 1994; Laws et al., 1995, Rau et al., 1997]. Therefore one could also argue that lower growth rates and/or high nutrients as prevailing under the ice led to higher fractionation and therefore low $\delta^{13} \mathrm{C}_{\text {org }}$ values.

Apart from core PS2163, $\delta^{13} \mathrm{C}_{\text {org }}$ values in the transitional period and in Termination I decrease and remain relatively constant, especially in cores PS2170 and PS2185. The $\delta^{15} \mathrm{~N}$ values during this interval are either similarly stable (PS2163) or begin to increase at the end of the glacial to the Holocene. Increasing TOC and carbonate values are characteristic for Termination I. During this time, the major deglaciation of the Barents Sea Ice Sheet [cf. Jones and Keigwin, 1988; Stein et al., 1994a; Elverhøi et al., 1995] occurred, which produced huge amounts of low-salinity meltwater floating over the normal ocean water. This water layer acted as a cover and caused poor ventilation of the lower water mass [Stein et al., 1994a; Norgaard-Pedersen et al., 1998] as indicated by low $\delta{ }^{13} \mathrm{C}_{\text {carbonate (foraminifera) values. }}$ Open leads, together with the nutrient-rich meltwater and river input, led to a higher production in surface waters as recorded by increasing TOC values. At this time, the transport mechanism for terrestrial organic matter most likely changed as described above from a more density- and turbidity currentcontrolled transport of material brought by rivers directly onto the slope during glacial times to transportation of terrestrial material entrained on the shelf by sea ice. This is confirmed by higher proportions of planktonic foraminifera in the carbonate fraction due to higher production and also higher IRD carbonate related to sea ice and iceberg melting [Vogt, 1997; Nørgaard-Pedersen et al., 1998]. The decrease in $\delta^{13} \mathrm{C}_{\text {org }}$ is possibly due to the fact that the phytoplankton now had plenty of nutrients and light, a fact that led to higher fractionation in culture studies [U. Riebesell, personal communications, 2000] and therefore lower $\delta^{13} \mathrm{C}_{\text {org }}$ values.

Following Termination $\mathrm{I}, \delta^{15} \mathrm{~N}$ and $\delta^{13} \mathrm{C}_{\mathrm{org}}$ steadily increase to modern values. The parallel increase in TOC and carbonate concentrations monitors the establishment of modern conditions. Today, we have a well-established low-salinity surface layer $(50-200 \mathrm{~m})$ in the Arctic Ocean [Anderson et al., 1994, Rudels et al., 1994]. This layer is well separated from the deep water, severely restricting nutrient exchange. Therefore, during the summer period, nutrients become depleted, forcing the phytoplankton, now in open-water regions (polynyas) and ice edges having enough light to grow, to utilize most of the nutrient supply. The increase in nutrient utilization leads to heavier $\delta^{15} \mathrm{~N}$ values in the nitrate pool according to (1), and assuming the same fractionation factor of nitrate uptake and diagenetic overprint, this leads to heavier $\delta^{15} \mathrm{~N}$ values, as observed in the sediments. In addition to open-water phytoplankton production, the increasing number of meltwater ponds, known to be very high productivity regimes [Gradinger, 1996], contribute to the higher overall production [cf. Schubert and Calvert, 2001]. This is strongly supported by higher organic carbon contents in the sediments (Figure 3). Total organic carbon accumulation rates are consistently $2-4$ times higher than during the last glacial (Table 1). Carbonate in the upper Holocene sections consists mainly of planktonic foraminifera and only minor amounts of ice-rafted carbonates [Stein et al., 1992; Vogt, 1997; Nørgaard-Pedersen et al., 1998] supporting the strong increase in surface water productivity. The increase in $\delta{ }^{13} \mathrm{C}_{\text {org }}$ resulted from a combination of factors: (1) higher growth rates and possibly lower $p \mathrm{CO}_{2}$ which led to higher $\delta^{13} \mathrm{C}_{\mathrm{org}}$ values of surface water phytoplankton; (2) higher input of marine organic matter with heavier $\delta^{13} \mathrm{C}_{\mathrm{org}}$ values; and (3) a larger influence of under ice algae (thinner ice cover leads to more light) and meltwater pond production. Since $\delta^{13} \mathrm{C}_{\text {org values of }}$ ice and meltwater pond phytoplankton are significantly heavier than "normal open ocean" plankton values ( -15.3 to 20.6\%, [Schubert and Calvert, 2001]), the increase in the production of these organisms might have the strongest impact on the $\delta^{13} \mathrm{C}_{\text {org }}$ signal of the sediments.

It is difficult to compare the sections of the cores older than the oldest AMS ${ }^{14} \mathrm{C}$ ages obtained in this study. However, some conclusions about possible oceanographic conditions in the Arctic Ocean prior to OIS 3 can be made on the basis of our core records. In core PS $2163, \delta^{15} \mathrm{~N}$ and $\delta^{13} \mathrm{C}_{\mathrm{org}}$ values similar to those measured in the Holocene are found below 19 $\mathrm{cm}$ depth. We therefore suggest an environment similar to modern conditions. An increased amount of planktonic foraminifera and the occurrence of $C$. wuellerstorfi, a species which also occurs in the Holocene but is absent in the cold intervals [Stein et al., 1994a] supports the enhanced productivity. Slightly heavier $\delta^{13} \mathrm{C}_{\text {org }}$ values in this interval might have resulted from the same factors mentioned above for Holocene sediments.

Core PS2170 shows in the interval $21-27 \mathrm{~cm}$, very light $\delta^{13} \mathrm{C}_{\text {carbonate values measured on the planktonic foraminifera }}$ N. pachyderma and interpreted by Stein et al. [1994a] as a huge meltwater event in the surface waters. During this time we found the nitrogen and carbon isotope ratios to be comparable to that of the Termination I event representing the deglaciation of the Barents Sea Ice Sheet [cf. Jones and Keigwin, 1988; Stein et al., 1994a; Elverhøi et al., 1995]. Low nitrogen isotope ratios show low nutrient utilization in the surface waters consistent with low productivity proposed by Norgaard-Pedersen et al. [1998] at the Termination I interval. At the position of core PS2178 we have a clear shift from heavy $\delta^{15} \mathrm{~N}$ values in the lowermost part of the core 
toward lighter values. These values are comparable to those in OIS 2, and we conclude therefore that similar conditions during that time prevailed. Further interpretation is not appropriate in view of the inadequate age control during this tıme interval.

In general, according to our results, $\delta^{15} \mathrm{~N}$ values are higher in Holocene sediments than in LGM sediments. This is in sharp contrast to the findings of Francois et al. [1992, 1997] who found higher LGM $\delta^{15} \mathrm{~N}$ values in sediments of the Southern Ocean, implicating higher nutrient utilization at this time, and suggested that the Southern Ocean was a major driver in the glacial atmospheric $\mathrm{CO}_{2}$ decrease. The Arctic Ocean would therefore act as a counterpart to the Southern Ocean during glacial as well as interglacial times. However, with very low production during glacial times and increased production (but also still low) during the Holocene combined with the rather small area involved, the influence of the Arctic Ocean on a global scale is probably low.

\section{Conclusions}

Nitrogen isotope ratios in Arctic Ocean sediments are useful indicators of relative nutrient utilızation by phytoplankton in surface waters. In comparison with productivity indicators, namely, TOC and carbonate concentrations, representing foraminiferal content and excluding IRD as well as comparison with foraminiferal counts [Nørgaard-Pedersen et al., 1998], sedimentary nitrogen isotope data appear to be closely linked to production changes. Additionally, variations in nitrogen isotope ratios seem to be heavily dependent on water column stratification and therefore the potential for nutrient exchange with the deepwater. Nitrogen isotope ratio varıations in Arctic Ocean sediments over the last 50,000 years have helped us to understand the relationships between surface water production, the extent of ice cover, and the exchange of nutrients between surface and deep waters. Carbon isotope ratio variations seem to be best interpreted as changes in surface water $p \mathrm{CO}_{2}$, growth rates of phytoplankton, and variations in the input of "heavy" ice algae material. Increasing $\delta^{15} \mathrm{~N}$ and $\delta^{13} \mathrm{C}_{\text {org }}$ in the cores during Termination I and the Holocene reflect higher nutrient utilization and productivity due to a diminishing ice cover and possible lower $p \mathrm{CO}_{2}$ and/or higher growth rates. During the LGM, low productivity and nutrient utilization in an ice covered ocean are monitored by light $\delta^{15} \mathrm{~N}$ values. Lighter carbon isotope ratios during these times reflect the relatively high $p \mathrm{CO}_{2}$ in the ice-covered surface waters and /or low growth rates. However, nutrient concentration, light conditions, or other factors influencing the carbon isotopic composition might also have played a significant role.

Acknowledgements. We thank Bente Nielsen for the isotope measurements Jochen Knies, Dirk Nuernberg, Christoph Vogt, Tom Pedersen, Stephanie Kienast, and Markus Kienast are thanked for numerous discussions We are grateful to the captain and crew of ARK-VIII/3 for their skıllful work during the expedition. We especially thank Roger Francois for sharıng his ideas with us and two anonymous reviewers for suggestions which significantly improved the final manuscript. C JS acknowledges a NATO fellowship from the German Academic Exchange Service (DAAD) and support from the Max Planck Society. $S$ E.C acknowledges financial support from the Natural Sciences and Engineerıng Research Council of Canada. The data presented in this paper are avalable from the World Data Center-A for Paleoclimatology http://www.ngde noaa gov/paleo).

\section{References}

Aargaard, K., and E.C. Carmack, The role of sea ice and other fresh water in the Arctic Circulation, J. Geophys Res, 94(C10), 14,485-14,498, 1989

Altabet, M.A, and R. Francois, Sedımentary nitrogen isotopic ratio as a recorder for surface ocean nitrate utilization, Global Biogeochem Cycles, 8(1), 103-116, 1994a.

Altabet, $\mathrm{M} \mathrm{A}$, and R. Francois, The use of nitrogen isotopic ratio for reconstruction of past changes in surface ocean nutrient utilization; in Carbon Cycling in the Glacial Ocean Constraints on the Ocean's Role on Global Change, NATO ASI Ser $C$, Vol.I 17, pp 281-306, edited by $R$. Zahn et al.., Springer Verlag, New York, 1994b.

Altabet, M.A., W.G Deuser, S Honjo, and C. Stienen, Seasonal and depth related changes in the source of sinking particles in the North Atlantic, Nature, 354, 136-139, 1991.

Altabet, M A., C. Pilskaln, R Thunell, C. Pride, D Sıgman, F. Chavez, and R. Francols, The nitrogen isotope biogeochemistry of sinking particles from the margin of the eastern North Pacific, Deep Sea Res Part I, 46, 655-579, 1999

Andersen, O G.N., Primary production, chlorophyll, light, and nutrients beneath the Arctic sea ice, in The Arctic Seas, edited by Y Herman, pp. 147 193, Van Nostrand Reınhold, New York, 1989

Anderson, L.G, G. Bjoerk, O. Holby, E.P Jones, G Kattner, K P Koltermann, B. Liljeblad, R Lindegren, B. Rudels, and J Swift, Water masses and circulation in the Eurasian Basin Results from the Oden 91 expedition, $J$. Geophys Res. 99 (C2), 3273-3283, 1994

Biggs, D C., S.P. Berkowitz, M.A. Altabet, R R. Bidıgare, D.J. DeMaster, R.B. Dunbar, A Leventer, S.A Macko, C.A. Nittrouer, and M.E. Ondrusek, A cooperative study of upper ocean particulate fluxes in the Weddell Sea, Proc Ocean Drill Program Initial Rep //3 (A), 77 $86,1988$.
Capone, D.G., J.P Zehr, H.W. Paerl, B. Bergmannn, and E.J. Carpenter, Trichodesmium, a globally significant marıne cyanobacterıum, Science, 276 , 1221-1229, 1997.

Carpenter, EJ, Nitrogen fixation by marine Oscillatoria (Trichodesmium) in the world's ocean, in Nitrogen in the Marine Environment, edited by E.J. Carpenter and D.G Capone, pp. 65-103, Academic, San Diego, Calıf,, 1983.

Carpenter, E J., and $\mathrm{K}$. Romans, Major role of the cyanobactenum Trichodesmium in nutrient cycling in the North Atlantic, Science, 254, 1356-1358, 1991

Carpenter, E.J., H R. Harvey, B Fry, and D.G. Capone, Biogeochemical tracers of the marine cyanobacterium Trichodesmium, Deep Sea Res Part I, 44, 27-38, 1997.

Curtın, T B., N. Untersteıner, and T Callaham, Arctic oceanography, Oceanus, 33, 58-66, 1990.

Driscoll, N.W., and G.H. Haug, A short circuit in themohaline circulation A cause for northern hemisphere glaciation?, Science, 282, 436-438, 1998.

Eglinton, G., and R.J. Hamilton, The distributions of alkanes, in Chemical Plant Toxonomy, edited by T. Swain, pp. 187-217, Academic, San Diego, Calif., 1963.

Elverhot, A., E.S. Andersen, T. Dokken, D Hebbeln, R F. Splelhagen, J.I. Svendsen, M. Sørflaten, A. Rørnes, $M$ Hald, and C.F. Forsberg. The growth and decay of the late Weichselian ice sheets in western Svalbard and adjacent areas based on provenance studies of marine sediments, Quat Res, 44, 303-316, 1995.

Fahl, K, and R. Steın, Modern organıc carbon deposition in the Laptev Sea and the adjacent continental slope' surface water productivity vs. terrigenous input, Org, Geochem , 26, 379-390, 1997.

Farrell, J.W., T.F. Pedersen, S E Calvert, and B. Nielsen, Glacial-ınterglacıal changes in nutrient utilization in the equatorial Pacific Ocean, Nature, 377, 514-517, 1995.

Francois, R., M.A. Altabet, and L.H. Burckle Glacial to interglacial changes in surface nitrate utılization in the Indian sector of the Southern Ocean as recorded by sediment $\delta^{15} \mathrm{~N}$, Paleoceanography, 7, 589-606, 1992.

Francois, R, M.A. Altabet, E.F. Yu, D.M. S1gman, M.P Bacon, M Frank, G. Bohrmann, G Bareille, and L.D. Labeyrie, Contribution of Southern Ocean surface-water stratification to low atmospheric $\mathrm{CO}_{2}$ concentrations during the last glacial period, Nature, 389, 929-935, 1997

Futterer, D K. (Ed), The expedition ARK-VIII/3 of RV "Polarstem" 1991, Ber Polarforsch, 107 267 pp., 1992.

Fütterer, D.K. (Ed.), The expeditıon Arctı'93, Leg ARK-IX/4 of RV "Polarstem" 1993, Ber. Polarforsch , 149, 244 pp , 1994.

Ganeshram, R.S., T.F Pedersen, S.E. Calvert, and J.W. Murray, Large changes in oceanıc nutrient inventories from glacial to interglacial periods, Nature, 376, 755-758, 1995.

Gradinger, R., Occurence of an algal bloom under Arctic pack ice, Mar Ecol Progr. Ser, 131 301-305, 1996

Heaton, T.H.E., The ${ }^{15} \mathrm{~N} /{ }^{14} \mathrm{~N}$ ratios of plants in South Africa and Namibia: Relationships to climate and coastal/salıne environments, Oecologıca, 74 236-246, 1987

Hedges, J.I., and J.R. Ertel, Characterization of lignin by gas capillary chromatography of cupric oxide oxidation products, Anal Chem., 54, 174-178, 1982

Hedges, J.I., and P.L. Parker, Land-derıved organıc matter in surface sediments from the Gulf of 
Mexico, Geochım Cosmochim Acta, 40, 1019. $1029,1976$.

Heımdal, B R , Phytoplankton and nutrients in the waters north-west of Spitzbergen in the autumn of 1979, J. Plankton Res., 5, 901-918, 1983

Hirche, H -J , M E.M Baumann, G Kattner, and $\mathbf{R}$ Gradinger, Plankton distribution and the impact of copepod grazıng on primary production in Fram Strait, Greenland Sea, J. Mar, Syst., 2, 477 494,1991 .

Holmes, M.E., P.J Müller, R.R. Schneıder, M. Segl, J. Paitzold, and G. Wefer, Stable nitrogen isotopes in Angola Basin surface sediments, Mar Geol, 134, 1-12, 1996.

Holmes, M.E., P.J. Muller, R.R. Schneıder, M. Segl, and $G$ wefer, Spatial variation in euphotic zone nitrate utilization based on $\delta^{15} \mathrm{~N}$ in surface sediments, Geo Mar. Lett., 18, 58-65, 1998

Johnson, G L , Morphology and plate tectonics The modern polar oceans, in Geological Histor of the Polar Oceans:Arctic versus Antarctic NATO ASI Series C Vol. 308, edited by U. Blell and J. Thiede, pp. 11-28, Kluwer Acad, Norwel Mass., 1990

Jones, G.A., and L.D. Keigwin, Evidence from Fram Strait $\left(78^{\circ} \mathrm{N}\right)$ for early deglaciation, Nature, 336 , 56-59, 1988.

Kıлаst, M., Unchanged nitrogen isotopic composition of organic matter in the South China Sea during the last climatic cycle Global implications, Paleoceanography, I5, 244-253, 2000

Laws, E.A., B N. Popp, R.R. Bıdıgare, M.C. Kennicutt, and S.A. Macko, Dependence of phytoplankton carbon isotopic composition on growth rate and $\left[\mathrm{CO}_{2}\right] \mathrm{aq}$. Theoretical considerations and experimental results, Geochim. Cosmochim. Acta, 59, 1131-1138, 1995.

Leo, R.F., and E.S Barghorn, Phenolic aldehydes: Generations from fossil woods and carbonaceous sedıments by oxıdative degradation, Science, $168,582-584,1970$.

Liu, K.K., and I.R. Kaplan, The eastem tropical Pacific as a source of ${ }^{15} \mathrm{~N}$-enriched nitrate in seawater off southern Califomia, Limnol. Oceanogr, 34(5), 820-830, 1989.

Marıttı, A., J.C. Germon, P. Hubert, P. Kaıser, R Letolle, A. Tardieux, and $P$. Tardieux, Experımental determination of nitrogen kınetic isotope fractionation. Some principles, illustration for the denitrification and nitrification processes, Plant Soil, 62, 413.430, 1981

Martinell, L.A., M.C. Piccolo, A.R. Townsend, P.M. Vitousek, E. Cuevas, W. McDowell, G.P. Robertson, O.C. Santos, and K. Treseder, Nitrogen stable isotopic composition of leaves and soil: Tropical versus temperate forests, Brogeochemistry, 46, 45-65, 1999.

Miyaka, Y., and E. Wada, The abundance ratio of ${ }^{15} \mathrm{~N} /{ }^{14} \mathrm{~N}$ in marine environments, Rec. Oceanogr Works Jpn, 9, 32-53, 1967

Montoya, J P, Nitrogen isotope fractionation in the modern ocean. Implications for the sedimentary record, in Carbon Cycling in the Glactal Ocean Constraints on the Ocean's Role on Global Change, NATO ASI Ser. C, Vol.I 17, pp. 259 279 , edited by R. Zahn et al.., Springer Verlag, New York, 1994.

Nardu, A.S, L.W. Cooper, B P. Finney, R.W Macdonald, C. Alexander, and I P. Semıletov, Organic carbon isotope ratios $\left(\delta^{13} \mathrm{C}\right)$ of Arctic Amerasian continental shelf sediments, Int $J$. Earth Scl, s005310000121, 1-12, 2000.

Nørgaard-Pedersen, N., Late Quaternary Arctic Ocean sedıment records Surface ocean conditions and provenance of ice-rafted debris, Ph.D. thesis, 115 pp Unıv. of Kıel, Kıel, Germany, 1996

Nørgaard-Pedersen, N., R.F. Spielhagen, J. Thiede, and $H$ Kassens, Central Arctic surface ocean environment during the past 80,000 years, Paleoceanography, 13, 193-204, 1998.
Nurnberg, D., I. Wollenburg, D Dethleff, H. Eicken, H. Kassens, T. Letzig, E. Reımnitz and J. Thiede, Sedıments in Arctic sea ice: Implications for entrainment, transport and release, Mar. Geol. $119,185-214,1994$.

Prahl, F G, and L.A. Muehlhausen, Lipid biomarkers as geochemical tools for paleoceanographic study, in Productivity of the Ocean Present and Past, edited by $\mathrm{W} \mathrm{H}$ Berger, V S. Smetacek, and G. Wefer, pp. 271 289 , John Wiley, New York, 1989

Prahl, F.G., J.R. Ertel, M.A. Gonı, M.A. Sparrow, and B Eversmeyer, Terrestrial organic carbon contributions to sediments on the Washington margin, Geochim Cosmochsm Acta, 58, 3035 . $3048,1994$.

Prıde, C., R. Thunell, D. Sigman, L. Keigwin, M. A. Altabet, and E. Tappa, Nitrogen isotopic variations in the Gulf of Calıfornia since the last deglaciation: Response to global climate change, Paleoceanography, 14, 397-409, 1999

Rau, G H., R.E. Sweeny, and I.R. Kaplan, Plankton ${ }^{13} \mathrm{C},{ }^{12} \mathrm{C}$ ratio changes with latitude: differences between northern and southern oceans, Deep Sea Res., 29, 1035-1039, 1982.

Rau, G.H., U. Riebesell, and D. Wolf-Gladrow, $\mathrm{CO}_{2}$ aq-dependent photosynthetic ${ }^{13} \mathrm{C}$ fractionation in the ocean: $A$ model versus measurements, Global Biogeochem. Cycles, II, 267-278, 1997.

Reddy, C.M., T.I. Eglinton, R. Palıc, B.C. BenitzNelson, G. Stojanovic, I. Palic, S. Djordjevic. and G. Eglinton, Even carbon number predominance of plant-wax $n$-alkanes. a correction, Org. Geochem., 3I, 331-336, 2000.

Reımnitz, E., and E.W. Kempema, Anchor ice, seabed freezing, and sediment dynamics in shallow arctic seas, J. Geophys. Res., 92(C13), $14,67 \mid-14,678,1987$

Reımnitz, E. and M. Saarso, Studies of sediment transport by ice, in Die Expedition Arktis VII-I, mit FS "Polarstern" 1990 , edited by J. Thiede and G. Hempel, Ber. Polarforsch., 80, 44-50, 1991

Rudels, B., E.P. Jones, L.G. Anderson, and G. Katmer, On the intermediate waters of the Arctic Ocean, in The Polar Oceans and Their Role in Shaping the Global Environment,Geophys. Monogr. Ser., vol. 85, edited by O.M Johannesen, R.D. Muench, , and J E. Overland, pp.33-46, AGU, Washington, D.C., 1994.

Schauer, U, B. Rudels, R.D. Muench, and L Timokhov, Circulation and water mass modifications along the Nansen Basin slope in Russian-German Cooperation Laptev Sea System, edited by $\mathrm{H}$. Kassenset al., Ber Polarforsch, 176, 94-106, 1995.

Schubert, C J, Organic carbon in late Quatemary Arctic Ocean sedıments: Terrıgenous supply and marine productivity, Ber. Polarforsch , 177, 178 pp., 1995

Schubert, C.J., and S.E. Calvert, Nitrogen and carbon isotopic composition of marine and terrestrial organic matter in Arctic Ocean sediments: Implıcations for nutrient utılızation and organic matter composition, Deep Sea Res. Part 1, 48, 789-810, 2001

Schubert, C.J., and R. Steın, Depositıon of organıc carbon in Arcuc Ocean sediments: terrigenous supply vs. marine productıvity, Org. Geochem., 24, 421-436, 1996

Schubert, C.J., and R. Steın, Lipıd distribution in surface sediments from the eastern central Arctic Ocean, Mar Geol, /38, 11-25, 1997.

Sejrup, H P , G.H. Miller, J. Brigham-Grette, R. Lovlıe, and D. Hopkins, Amıno acid epımerization implies rapıd sedimentation in Arctic Ocean cores, Nature, 310, 772-775, 1984.

Sigman, D.M, M A. Altabet, R Michener, D. McCorckle, B. Fry, and R. M. Holmes, Natural abundance-level measurement of the nitrogen
Isotopic composition of oceanic nitrate: An adaptation of the ammonia diffusion method, Mar Chem., 57, 227-242, 1997.

Sıgman, D.M., M. A. Altabet, R Francois, D McCorckle and J.-F Gaillard, The isotopic composition of diatom-bound nitrogen in Southern Ocean sediments, Paleoceanography, 14, 118-134, 1999a.

Sıgman, D.M., M. A. Altabet, D. McCorckle, R. Francois, and $\mathrm{G}$ Fischer, The $\delta^{15} \mathrm{~N}$ of nitrate in the Southern Ocean. Consumption of nitrate in surface waters, Global Biogeochem Cycle, 13, $1149-1166,1999 \mathrm{~b}$.

Sigman, D.M, M A Altabet, D McCorckle, R. Francoss, and G. Fischer, The delta $0^{15} \mathrm{~N}$ of nitrate in the Southern Ocean: Nitrogen cycling and circulation in the ocean interior, $J$. Geophys Res., $105(\mathrm{C} 8)$, 19,599-19,614,2000.

Steın, R, Arctıc Paleo-River Discharge (APARD), A new research programme of the Arctic Ocean Science Board (AOSB), Ber. Polarforsch., 279, 128 pp., 1998.

Stein, R., Circum-Arctic river discharge and its geological record: An introduction, Int. J. Earth Sci., s0053/0000110, 1-3, 2000.

Steın, R , C.J. Schubert, H. Grobe, and D. Fütterer, Late Quaternary changes in sediment composition in the central Arctic Ocean: Preliminary results of the Arctic' 91 expedition, in International conference on Arctic Margins 1992 Proceedings, edited by D.K Thurston and K. Fujita, MMS94-0040, pp. 363-368, U S. Department of the Interior, Anchorage, Alaska, 1992.

Stein, R., S.-I. Nam, C.J. Schubert, C. Vogt, D. Futterer, and $\mathrm{J}$. Heinemeier, The last deglaciation event in the eastern central Arctic Ocean, Science, $264,692-696,1994 \mathrm{a}$.

Stein, R, H. Grobe, and M. Wahsner, Organıc carbon, carbonate, and clay mineral distributions in eastem centra! Arctic Ocean surface sediments, Mar Geol. 119, 269-285, 1994b.

Subba Rao, D.V., and T Platt, Primary Production of Arctic Water, Polar Biol., 3, 191-201, 1984.

Thompson, P.A. and S.E. Calvert, Carbon-isotope fractionation by marine diatom: The influence of Irradiance, daylight, $\mathrm{pH}$, and nitrogen source, Limnol Oceanogr , 39, 1835-1844, 1994.

Thornton, S.F., and J. McManus, Application of organic carbon and nitrogen stable isotope and $\mathrm{C} / \mathrm{N}$ ratios as source indicators of organic matter provenance in estuarine sediments Evidence from the Tay Estuary, Scotland, Estuarine Coastal Shelf Sct , 38, 219-233, 1994

Vogt, C, Regional and temporal variations of mineral assemblages in Arctic Ocean sediments as climatic indicator during glacial/interglacial changes, Ber Polarforsch, 251, 309 pp., 1997.

Voss, M., M. A. Altabet, and V. Bodungen, $\delta^{15} \mathrm{~N}$ in sedimenting particles as indicator of euphoticzone processes, Deep Sea Res. Part I, 43, 33-47, 1996.

Wada, E., and A. Hattors, Nitrogen isotope effects in the assimilation of morganic nitrogenous compounds by marine diatoms, Geomicrobiol $J, l(1), 85-101,1978$.

Wada, E., and A. Hattorı, Nitrogen in the Sea Forms, Abundances, and Rate Processes, CRC Press,Boca Raton, Fla., 1991

Wada, E., M. Mınagawa, H. Mızutanı, T Tsujı, R Imaizumı, and $\mathrm{K}$ Karasawa, Biogeochemical studies on the transport of organic matter along the Otsuchı River watershed, Japan, Estuarine Coastal Shelf Sci., 25, 321-336, 1987b.

Wada, E., M Terazakı, Y. Kabaya, and T. Nemoto, ${ }^{15} \mathrm{~N}$ and ${ }^{13} \mathrm{C}$ abundances in the Antarctic Ocean with emphasis on the biogeochemical structure of the food web, Deep Sea Res Part I, 34, 829 . 841,1987 a

Wheeler, P A., M. Gosselın, E. Sherr, D. Thıbault, D.L. Kirchman, R Benner, and T E Whitledge, 
Active cycling of organic carbon in the central Arctic Ocean, Nature, 380, 697-699, 1996.

Wollenburg, I., Sedimenttransport durch das arktısche Meereıs: Die rezente lithogene und biogene Matenalfracht, Ber. Polarforsch, 27, $159 \mathrm{pp}, 1993$.

Wu, J., S.E. Calvert, and C. Wong, Nitrogen isotope variations in the subarctic northeast

Pacıfic: Relationshıps to nitrate utilization and trophic structure, Deep Sea Res Part I, 44, 287 -

$$
314,1997 .
$$

S.E. Calvert, Earth and Ocean Sciences, University of Britısh Columbia, 6270 University Boulevard, Vancouver, British Columbıa, Canada V6T 1Z4.

C J. Schubert, Max Planck Institute for Marıne Microbiology, Celsiusstrasse 1, 28359 Bremen, Germany.

R Stein, Alfred Wegener Institute for Polar and
Marine Research, Columbusstrasse, 27515 Bremerhaven, Germany.

calvert@eos ubc.ca, cschuber@mpi-bremen.de, rsteın@awı-bremerhaven.de

(Received January 23,2000

revised October 23, 2000

accepted November 27, 2000) 